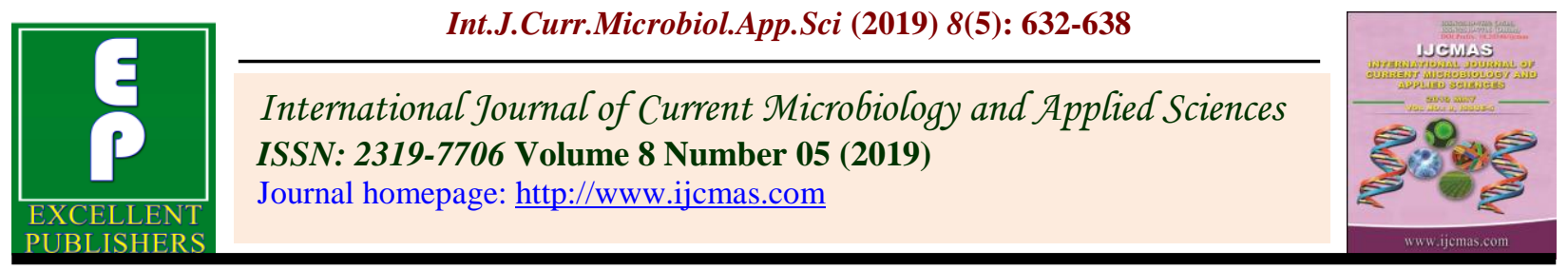

Original Research Article

https://doi.org/10.20546/ijcmas.2019.805.073

\title{
Response on Growth and Yield of Maize as Affected by Different Intercropping Systems under Rubber Plantation in Hill Areas of Nagaland
}

\author{
K. Samuel Sangtam ${ }^{1^{*}}$, N. Khumdemo Ezung ${ }^{2}$ and Tiatula Jamir ${ }^{3}$ \\ ${ }^{1}$ KVK Mokokchung, Government of Nagaland, Department of Agriculture, \\ Mokokchung-798614, Nagaland, India \\ ${ }^{2}$ KVK Kiphire, ICAR Research Complex for NEH Region Nagaland Centre, \\ Medziphema-797106, Nagaland, India \\ ${ }^{3}$ Agriculture Technology Management Agency, Wokha, Government of Nagaland, \\ Department of Agriculture, Wokha-797111, Nagaland, India \\ *Corresponding author
}

\section{A B S T R A C T}

\section{Keywords}

Intercropping, Maize based, Rubber plantation, Growth, Yield

Article Info

Accepted:

07 April 2019

Available Online:

10 May 2019
A field experiment was conducted during the kharif season of the year 2017 and 2018 at the experimental farm of Krishi Vigyan Kendra, Mokokchung, Nagaland to assess the response on growth and yield of maize crop as affected by different intercropping system under rubber plantation. The experiment was laid out in "Randomised Block Design" with seven treatments and three replications. The treatments include sole maize, maize + frenchbean, maize + groundnut, maize + paddy, maize + ginger, maize + greengram and maize + turmeric. It was found that the growth and yield of the sole crop out-performed the rest of the intercropping system. However, it was found that maize + ginger intercropping produced the highest system yield, maize equivalent yield, net income and $\mathrm{B}: \mathrm{C}$ ratio as compared with the rest of the intercropping system. It can, therefore be concluded that, intercropping of maize with ginger followed by maize+ turmeric may be considered for adoption by farmers' of Mokokchung district. The intercropping of maize + french bean which resulted in the $\mathrm{B}: \mathrm{C}$ ratio of 1.85 may also be considered for taking up under rubber plantation, since inclusion of legumes in the cropping system results in maintaining the soil sustainability.

\section{Introduction}

In the North Eastern Region of India, maize is an important cereal crop having high potentiality for large scale cultivation, but the current production is still lower in comparison to our national average even though it is the second- most important cereal crop of the region next to rice. Maize is primarily grown in shifting cultivation covering 42 per cent. This region is one of the major maize growing belt covering an area of more than 137.2 thousand hectares with an average productivity of $1265 \mathrm{~kg} / \mathrm{ha}$ (Vinay et al.,1996). In Nagaland alone, maize is cultivated in an area of 35 thousand hectares with a total production of 50 thousand tones (Anonymous, 2001). 
Intercropping is an old practice of crop production and this system has been developed under condition involving both risk and constraints particularly vagaries of weather and incidence of pests and diseases which limit crop production. Intercropping leads to better utilization of resources in terms of space and time (Palaniappan, 1989). Intercropping system is a well developed technology for monoculture, and intercropping will no longer be just a poor man's practice. Thus, various evidences suggest that intercropping can in fact; provide a substantial yield advantage compared to sole cropping and is recognized as a beneficial system of crop production.

Of all the intercrops, various experiments indicated that legumes have more advantages when intercropped with maize due to its greater land-use efficiency per unit area, higher yield, fixation of atmospheric nitrogen and sharing complimentary effects between the component crops. In intercropping systems, crops are so selected that they differ in their plant height, canopy structure, growth habit and maturity duration so that there is less competition among them. Intercropping systems reduces the value of yield attributes and grain yield of maize than sole cropping of maize, but, it recorded higher maizeequivalent yield, productivity ( $\mathrm{kg} / \mathrm{ha} /$ day) and significant reduction in weed population and weed dry- biomass than sole cropping of maize (Pandey et al., 2003).

Maize intercropping can be successfully carried out under rubber plantation, a commercial crop which is becoming very popular in the Mokokchung district of Nagaland. The vacant spaces between rubber trees can be utilized for raising some field and horticultural crops during the initial years of rubber plantation. In order to utilize the vacant spaces optimally, maize-based intercropping could be undertaken so that it may substantially increase the yield of cropping system. Maize along with ginger, turmeric, rice, groundnut, green gram and french bean could be raised as component crops in rubber plantation.

Keeping in view the above facts, the experiment was conducted to study the feasibility of maize based intercropping under rubber plantation.

\section{Materials and Methods}

A field trial was carried out during kharif season of the year 2017 and 2018 at the experimental farm of Krishi Vigyan Kendra, Mokokchung, Nagaland. The experiment was laid out in "Randomised Block Design" with seven treatments and three replications. The treatments consisted of various intercrop with maize as the base crop. The intercrop consisted of French bean, groundnut, paddy, ginger, greengram and turmeric.

The climatic condition of the experimental site is sub-tropical in nature. The average annual rainfall varies between $1500-2000 \mathrm{~mm}$. Most of the rainfall occurs during May to October. The mean temperature ranges from $21^{\circ} \mathrm{C}$ to $30^{\circ} \mathrm{C}$ during summer and goes below $8^{\circ} \mathrm{C}$ in winter. The soil of the experimental field was sandy loam in texture, deep and well drained.

\section{Results and Discussion}

\section{Effect of intercropping on growth attributes}

Intercropping treatments had significant effect on the plant height at all the stages of its growth during both the years. Significantly taller plants of maize were observed in sole maize at 30, 60 DAS and at harvest (Table 1). This finding may be attributed to the absence of intercrop competition in sole maize. 
Similar results were also obtained by Manpreet et al., (2016) in sole maize than with cowpea intercrop. Among the intercropping treatments, maize + ginger intercropping was recorded to be the best in terms of plant height at 30,60 DAS as well as at harvest. Plant height of maize is also an important factor responsible for growth and yield which may be influenced by a number of genetic factors and abiotic factors.

Dry matter accumulation increased with the increase in crop growth. The plant dry matter accumulation per plant of sole maize was superior over other intercropping treatments (Table 2). It could be attributed to the absence of competition between the crops. Maize + rice intercropping recorded the least plant dry matter accumulation at all the stages. Similar results were also reported by Lingaraju, et al., (2008) indicating significantly lower dry matter yield in maize + groundnut intercropping than sole maize.

The observation on number of leaves per plant showed that sole crop maize retained the highest number of leaves which was closely followed by maize + ginger intercropping at 30, 60 DAS and at harvest (Table 3) indicating its superiority over other intercropping treatments. The lowest number of leaves/plant was recorded in maize + turmeric treatment.

\section{Effect of intercropping on yield attributes}

The intercropping treatment had significant impact on the number of cobs per plant during both the years. The maximum number of cobs per plant was observed in sole crop. Manpreet et al., (2016) also reported similar findings. The number of cobs per plant recorded in maize + ginger intercropping was found to be statistically at par with maize + french bean intercropping treatment. The minimum number of cobs per plant was observed in maize + rice intercropping which was at par with maize + groundnut and maize + green gram intercropping treatments (Table 4).

The study also revealed that different intercropping treatments had significant effect on the number of grains per cob. The highest number of grains per cob was recorded from sole crop which was found to be statistically at par with maize + ginger intercropping. The minimum number of grains per cob was recorded in maize + groundnut intercropping which was significantly inferior than rest of the intercropping treatments. Within the intercropping treatments, maize + ginger and maize + french bean was recorded comparable number of grains per cob and were significantly superior from the other intercropping treatments (Table 4). These result are in line with the findings of Moses et al.,(2002).

Similarly, sole crop also recorded the maximum test weight and was statistically superior over the rest of the intercropping treatments. Whereas, maize + turmeric intercropping treatment recorded the minimum test weight. Intercropping treatments viz., maize + green gram, maize + french bean and maize + groundnut were found to be statistically at par but were significantly superior to maize + rice (Table 4).

The highest grain yield of maize $(25.14 \mathrm{q} / \mathrm{ha})$ was obtained in sole cropping of maize which might be due to higher values of yield attributing characters as there was lower competition for space, moisture and nutrients, etc., in sole cropping as compared to intercropping. This result confirmed the findings of Sultana et al., (2013) who reported that the yield and yield related components of maize and legumes were reduced over respective sole cropping. In the present intercropping treatments, maize grain yield 
was obtained highest when intercropped with maize + ginger intercropping which was also found at par with sole maize and the lowest maize grain yield was recorded with maize + rice intercropping (Table 5).

Sole crop had the highest stover yield which was followed by maize + ginger intercropping. Among the intercropping treatments maize + ginger, maize + turmeric and maize + rice were found to be statistically at par with each other. Remaining intercropping treatments viz; maize + french bean, maize + green gram and maize + groundnut were recorded comparable maize stover yield. Maize + rice intercropping showed the least stover yield and were very much inferior from the rest of the intercropping treatments. These results are in line with the findings of Lingaraju, et al., (2008) who obtained more grain and stover yield in sole cropping (Table 5).

The yield of component crops as influenced by maize based intercropping were $35.26 \mathrm{q} / \mathrm{ha}$ in maize + turmeric, $41.25 \mathrm{q} / \mathrm{ha}$ in maize + ginger, $2.57 \mathrm{q} / \mathrm{ha}$ in maize + green gram, 7.17 $\mathrm{q} / \mathrm{ha}$ in maize + french bean, $6.31 \mathrm{q} / \mathrm{ha}$ in maize + groundnut and $2.73 \mathrm{q} / \mathrm{ha}$ in maize + rice indicating significant difference at $5 \%$ probability level in maize equivalent yield was mainly due to additional yield advantage in intercropping.

Table.1 Height of maize plant $(\mathrm{cm})$ as influenced by intercropping

\begin{tabular}{|c|c|c|c|}
\hline \multirow{2}{*}{ Treatment } & \multicolumn{3}{|c|}{ Days after sowing } \\
\cline { 2 - 4 } & $\mathbf{3 0}$ & $\mathbf{6 0}$ & At harvest \\
\hline Sole maize & 78.52 & 169.00 & $\mathbf{2 2 3 . 2 5}$ \\
\hline Maize + ginger & 73.59 & 165.08 & $\mathbf{2 1 6 . 5 0}$ \\
\hline Maize + turmeric & 64.07 & 154.25 & $\mathbf{2 0 4 . 0 0}$ \\
\hline Maize + green gram & 58.87 & 143.41 & $\mathbf{2 0 3 . 6 6}$ \\
\hline Maize + french bean & 72.68 & 139.58 & $\mathbf{1 9 4 . 1 6}$ \\
\hline Maize + ground nut & 62.54 & 152.75 & $\mathbf{1 9 9 . 5 8}$ \\
\hline Maize + rice & 50.08 & 127.33 & $\mathbf{1 8 1 . 2 6}$ \\
\hline SEm $( \pm)$ & $\mathbf{1 . 7 9}$ & $\mathbf{3 . 9 1}$ & $\mathbf{4 . 4 9}$ \\
\hline CD $(\mathbf{P}=\mathbf{0 . 0 5})$ & $\mathbf{5 . 5 3}$ & $\mathbf{1 2 . 0 5}$ & $\mathbf{1 3 . 8 5}$ \\
\hline
\end{tabular}

Table.2 Maize dry matter accumulation (g) as influenced by intercropping

\begin{tabular}{|c|c|c|c|}
\hline \multirow{2}{*}{ Treatment } & \multicolumn{3}{|c|}{ Days after sowing } \\
\cline { 2 - 4 } & $\mathbf{3 0}$ & $\mathbf{6 0}$ & At harvest \\
\hline Sole maize & 2.29 & 41.16 & $\mathbf{5 7 . 7 9}$ \\
\hline Maize + ginger & 1.98 & 37.85 & $\mathbf{5 4 . 1 7}$ \\
\hline Maize + turmeric & 1.88 & 35.60 & $\mathbf{5 2 . 1 1}$ \\
\hline Maize + green gram & 1.94 & 37.63 & $\mathbf{5 4 . 7 6}$ \\
\hline Maize + french bean & 1.59 & 33.82 & $\mathbf{4 6 . 4 7}$ \\
\hline Maize + ground nut & 1.48 & 29.07 & $\mathbf{3 7 . 2 5}$ \\
\hline Maize + rice & 1.69 & 35.25 & $\mathbf{4 8 . 3 0}$ \\
\hline SEm ( \pm ) & 0.074 & 2.00 & $\mathbf{1 . 1 4}$ \\
\hline CD $(\mathbf{P = 0 . 0 5 )}$ & $\mathbf{0 . 2 2}$ & $\mathbf{6 . 1 7}$ & $\mathbf{3 . 5 3}$ \\
\hline
\end{tabular}


Table.3 Number of leaves (maize) as influenced by intercropping

\begin{tabular}{|c|c|c|c|}
\hline \multirow{2}{*}{ Treatment } & \multicolumn{3}{|c|}{ Days after sowing } \\
\cline { 2 - 4 } & $\mathbf{3 0}$ & $\mathbf{6 0}$ & At harvest \\
\hline Sole maize & 8.16 & 12.75 & $\mathbf{1 2 . 5 0}$ \\
\hline Maize + ginger & 8.08 & 12.41 & $\mathbf{1 2 . 2 5}$ \\
\hline Maize + turmeric & 7.66 & 12.16 & $\mathbf{1 1 . 4 1}$ \\
\hline Maize + green gram & 7.41 & 10.66 & $\mathbf{1 1 . 1 6}$ \\
\hline Maize + french bean & 7.91 & 11.50 & $\mathbf{1 1 . 3 3}$ \\
\hline Maize + ground nut & 7.66 & 11.83 & $\mathbf{1 1 . 0 0}$ \\
\hline Maize + rice & 7.4 & 11.91 & $\mathbf{1 0 . 5 0}$ \\
\hline SEm $( \pm)$ & 0.19 & 0.13 & $\mathbf{0 . 1 8}$ \\
\hline CD $(\mathbf{P}=\mathbf{0 . 0 5})$ & $\mathbf{0 . 5 9}$ & $\mathbf{0 . 4 2}$ & $\mathbf{0 . 5 7}$ \\
\hline
\end{tabular}

Table.4 Number of cobs/plant, number of grains/cob and test weight (g) as influenced by intercropping

\begin{tabular}{|c|c|c|c|}
\hline Treatment & No. of cobs/plant & No. of grains/cob & Test weight $(\mathbf{g})$ \\
\hline Sole maize & 1.33 & 358.33 & $\mathbf{2 3 4 . 7 2}$ \\
\hline Maize + ginger & 1.33 & 339.67 & $\mathbf{2 2 0 . 7 0}$ \\
\hline Maize + turmeric & 1.00 & 315.00 & $\mathbf{2 1 1 . 1 0}$ \\
\hline Maize + green gram & 1.25 & 338.33 & $\mathbf{2 0 9 . 2 3}$ \\
\hline Maize + french bean & 1.08 & 206.00 & $\mathbf{2 1 0 . 8 9}$ \\
\hline Maize + ground nut & 0.91 & 237.00 & $\mathbf{1 9 2 . 3 4}$ \\
\hline Maize + rice & 1.00 & 268.67 & $\mathbf{1 8 2 . 5 7}$ \\
\hline SEm $( \pm)$ & 0.06 & 6.23 & $\mathbf{2 . 7 4}$ \\
\hline CD $(\mathbf{P}=\mathbf{0 . 0 5})$ & $\mathbf{0 . 2 0}$ & $\mathbf{1 9 . 2 1}$ & $\mathbf{8 . 4 4}$ \\
\hline
\end{tabular}

Table.5 Maize yield, maize stover yield and maize equivalent yield as influenced by intercropping (q/ha)

\begin{tabular}{|c|c|c|}
\hline Treatment & Maize grain yield $(\mathbf{q} / \mathbf{h a})$ & Stover yield $(\mathbf{q} / \mathbf{h a})$ \\
\hline Sole maize & 25.14 & $\mathbf{5 7 . 9 1}$ \\
\hline Maize + ginger & 24.51 & $\mathbf{5 5 . 4 1}$ \\
\hline Maize + turmeric & 19.25 & $\mathbf{5 3 . 9 5}$ \\
\hline Maize + green gram & 20.74 & $\mathbf{4 6 . 8 7}$ \\
\hline Maize + french bean & 13.79 & $\mathbf{4 8 . 8 4}$ \\
\hline Maize + ground nut & 11.45 & $\mathbf{3 7 . 7 0}$ \\
\hline Maize + rice & 14.53 & $\mathbf{5 2 . 9 1}$ \\
\hline SEm $( \pm)$ & 0.56 & $\mathbf{3 . 9 7}$ \\
\hline CD $(\mathbf{P}=\mathbf{0 . 0 5})$ & $\mathbf{1 . 7 2}$ & $\mathbf{1 2 . 2 4}$ \\
\hline
\end{tabular}


Table.6 Economics of treatments

\begin{tabular}{|c|c|c|c|c|}
\hline Treatment & $\begin{array}{c}\text { Cost of cultivation } \\
\text { (Rs./ha) }\end{array}$ & $\begin{array}{c}\text { Gross return } \\
\text { (Rs./ha) }\end{array}$ & $\begin{array}{c}\text { Net return } \\
\text { (Rs./ha) }\end{array}$ & B:C ratio \\
\hline Sole maize & 20000 & 62850 & 42850 & $\mathbf{2 . 1 4}$ \\
\hline Maize + ginger & 45000 & 214020 & 176770 & $\mathbf{4 . 7 5}$ \\
\hline Maize + turmeric & 37250 & 214800 & 169800 & $\mathbf{3 . 7 7}$ \\
\hline Maize + greengram & 28560 & 67180 & 38620 & $\mathbf{1 . 3 5}$ \\
\hline Maize + french bean & 27260 & 77770 & 50510 & $\mathbf{1 . 8 5}$ \\
\hline Maize + ground nut & 29680 & 73380 & 43700 & $\mathbf{1 . 4 7}$ \\
\hline Maize + rice & $\mathbf{1 6 2 5 0}$ & $\mathbf{3 4 5 2 0}$ & $\mathbf{1 8 2 7 0}$ & $\mathbf{1 . 1 2}$ \\
\hline
\end{tabular}

Higher maize equivalent yield under intercropping than sole cropping of maize was also reported by Balasubramanium et al., (1989), Balyan and Seth (1989) and Sharma et al., (1998).

\section{Economics}

It is evident from the data presented in Table 6 that the maximum net return per hectare was obtained from maize + ginger $(176770)$ intercropping followed by maize + turmeric (169800) and maize + frenchbean (50510) intercropping treatments. Result of higher net returns might be due to higher yields of components crops and higher market price of the intercrop. Among the intercropping treatments, maize + rice (18270) gave the minimum net return from rest of the intercropping treatments.

A perusal of data presented in Table 6, revealed that the maximum benefit: cost ratio was recorded from maize + ginger (4.75) intercropping treatment followed by maize + turmeric (3.77) intercropping treatments which was due to higher production and better market price of the intercrop. Whereas, maize + rice (1.12) intercropping treatment gave minimum benefit: cost ratio which might be due to severe competition among the crops.
From the above findings, it can be concluded that, intercropping of maize with ginger which gave the highest net return and $\mathrm{B}: \mathrm{C}$ ratio followed by maize+ turmeric may be considered for adoption by farmers' of Mokokchung district. The intercropping of maize + french bean which resulted in the $\mathrm{B}: \mathrm{C}$ ratio of 1.85 may also be considered, since inclusion of legumes in the cropping system results in maintaining the soil sustainability.

\section{References}

Anonymous., 2001. Area and production of maize in Nagaland; Directorate of Agriculture, Government of Nagaland.

Manpreet, K., Thakur, N.P., Kumar, P. and Charak, A.S., 2016. Productivity and profitability of maize (Zea mays) as influenced by intercropping of rajmash (Phaseolus vulgaris) and nutrient management techniques under sub-alpine conditions of Jammu, India. Legume Research. 39 (6): 970975.

Lingaraju, B.S., Marer, S.B., and Chandrashekar. S. S., 2008. Studies on intercropping of maize and pigeonpea under rainfed conditions in northern transitional zone of Karnataka. Karnataka J. Agric. Sci., 21 (1): 1-3. 
Moses, G.B., Kaiira, M., Ikramullah and Shaik, M., 2002. Performance of maize in intercropping with legumes at different levels of fertilizers. Crop Research. 20(1):149-151.

Palaniappan, S.P., Balasubramanium, A., and Ramaswami, C., 1976. Intercropping sorghum with legumes for saving nitrogen. Sorghum Newsletter. 19: 86.

Pandey, I.B., Bharati, V., and Mishra, S.S., 2003. Effect of maize-based intercropping systems on maize yield and associated weeds under rainfed condition. Indian Journal of Agronomy. 48(1): 30-33.

Sultana, S.R., Tariq, M., Ahmad, A. and Naseem, W., 2013. Productivity of some maize based intercropping systems under different planting geometries. Thai Journal of Agricultural Science. 46(2): 65-70.

Vinay, M., Gupta, H.S., and Sharma, B. K., 1996. Population development in maize suitable for North Easter Hill Region. Technical Bulletin. 12 ICAR, New Delhi.

\section{How to cite this article:}

Samuel Sangtam, K., N. Khumdemo Ezung and Tiatula Jamir. 2019. Response on Growth and Yield of Maize as Affected by Different Intercropping Systems under Rubber Plantation in Hill Areas of Nagaland. Int.J.Curr.Microbiol.App.Sci. 8(05): 632-638. doi: https://doi.org/10.20546/ijcmas.2019.805.073 